\title{
De waarde van Intervention Mapping en de Theory of Planned Behavior voor de effectiviteit van een communicatietraining
}

\section{Michael Rauner, Gerjo Kok, Toon Taris*}

Blijvende gedragsverandering als gevolg van een training blijkt in de praktijk moeilijk te realiseren. In de huidige studie wordt verondersteld dat een dergelijke verandering langer zal beklijven indien er (1) gebruik wordt gemaakt van een theoriegestuurd interventieprogramma (gebaseerd op de 'Theory of Planned Behavior', Ajzen, 1991), dat (2) geïmplementeerd wordt volgens een gestructureerde methode ('Intervention Mapping', Bartholomew et al., 2001). In een gecontroleerd trainingsprogramma met een interventie- ( $N=35$ ) en een controlegroep ( $N=19$ ) bleek dat het TPB-model een effectief instrument is om gedrag in te kaderen en het effect van gedragsverandering te meten. IM bleek zoals verwacht een effectieve strategie om gedrag op langere termijn (follow-up na drie maanden) positief te beïnvloeden. Daarbij werd voor de interventiegroep een significante verbetering op alle variabelen uit het TPB-model aangetroffen, in tegenstelling tot de controlegroep waar geen significante veranderingen werden waargenomen.

Trefwoorden: training, attitude-gedrag model, gedragsverandering, Intervention Mapping, evaluatie

* Michael Rauner is zelfstandig organisatieadviseur en daarnaast verbonden aan de Faculteit Psychologie van de Universiteit Maastricht. Correspondentieadres: Drs. M. Rauner, Fazantenlaan 12, 6865 WL Doorwerth. Telefoon: (026) 4462881, fax: (026) 4434406, e-mail: info@rauner.nl.

Gerjo Kok, Universiteit Maastricht.

Toon Taris, Radboud Universiteit Nijmegen. 


\section{Inleiding}

Nederland kent een positief klimaat voor opleidingen en trainingen. Gemiddeld wordt 2 tot 3 procent van de loonsom geïnvesteerd in de individuele ontwikkeling van medewerkers (CBS, 2002); per jaar volgt gemiddeld rond 57 procent van de werknemers in een organisatie een vorm van opleiding. De directe kosten voor vakopleidingen bedroegen in 1999 al meer dan $€ 3$ miljard, waarbij de verloren loonkosten nog niet zijn meegenomen (CBS, 2002) en de tendens is stijgend. Sindsdien is de vraag naar het nut en de effectiviteit van opleidingen en trainingen steeds belangrijker geworden vanwege onder meer de teruggang van de economische groei (na II september 2000), de stijgende werkloosheid en de sinds 200 I explosief gestegen productiekosten. Organisaties willen meer dan ooit van tevoren een inschatting kunnen maken van de kosten voor opleidingen en de mogelijke opbrengsten daarvan op langere termijn (Van Lakerveld, Oudendammer \& Stam, 2003). Interessant genoeg heeft deze laatste ontwikkeling onder andere binnen de wereld van gedragstrainingen niet geleid tot grote verandering van de inhoud van de aangeboden interventies, noch in de manier waarop deze worden geëvalueerd. In nog mindere mate wordt onderzoek uitgevoerd naar de omstandigheden waaronder het aangeleerde gedrag daadwerkelijk wordt vertoond en wat het resultaat op lange termijn is; evaluatie van de effecten van gedragstrainingen is nog steeds tamelijk ongebruikelijk.

Ook in de wetenschap wordt steeds meer nadruk op de effectiviteit, efficiëntie en transfer van opleidingen gelegd (Den Ouden, 1992; Salas \& Cannon-Bowers, 200I), en er zijn steeds meer aanwijzingen dat voor gedragstrainingen vooral een gestructureerde maatwerkaanpak goede kansen op gewenste gedragsverandering biedt (bijvoorbeeld Schaalma, I993; Schaalma, Kok \& Meertens, 200I). Eén mogelijke oorzaak voor het achterblijven van de praktijk bij de stand van zaken in de wetenschap is dat het voor practici op dit moment nog onvoldoende duidelijk is wat de meetbare meerwaarde van een maatwerkaanpak kan zijn en hoe mogelijke effecten kunnen worden gemeten.

Doel van dit artikel is binnen een gedragstraining inzicht te geven in de vraag of een programma waarin gericht terugkoppeling wordt gegeven op variabelen die van invloed zijn op het gedrag van de deelnemers een versterkend effect heeft op de gedragsintentie ten opzichte van een programma waarin dat niet wordt gedaan. Tevens wordt onderzocht in hoeverre het aan te leren gedrag daarbij verandert, in overeenstemming met de beoogde doelstelling van de training. Hiertoe wordt de gedragsverandering van een op maat ontwikkeld programma voor een communicatietraining vergeleken met een standaardprogramma binnen een opleiding bij een Nederlandse multinational.

Als basisconcept is Ajzen's (I99I) theorie van gepland gedrag ('Theory of Planned Behavior, TPB) gebruikt om het effect van de training op de gewenste gedragsverandering te evalueren en te verklaren. De participanten aan het standaardprogramma kregen een reguliere training die zich volgens een vaststaand draaiboek richtte op het verwerven van basale communicatieve vaardigheden. De groep met een maatwerkprogramma kreeg een training met dezelfde doelstelling waarin met behulp van het TPB-model (Ajzen, 199I) de persoonlijke leerdoelen geanalyseerd zijn en gedurende de training per deelnemer aan specifieke oefeningen gekoppeld zijn. 
De inhoud van deze training was met name gericht op het verwerven van basale communicatievaardigheden (luisteren, samenvatten, doorvragen), feedback op het werk (kunnen geven en ontvangen), duidelijkheid in de omschreven werkzaamheden verwerven, kritiek kunnen geven en ontvangen, en vergroten van de assertiviteit (Bender et al., 20or; Van Dijk, I998). Het effect kan worden gemeten in termen van het toepassen van de bedoelde vaardigheden (in sommige gevallen meer, in andere gevallen juist minder van het bedoelde gedrag vertonen) waardoor de doelmatigheid en de resultaten van het vertoonde gedrag toenemen. De opzet en het ondersteunende materiaal van beide trainingen was identiek wat betreft de behandelde onderwerpen. Ook zijn in beide groepen door de deelnemers persoonlijke leerdoelen opgesteld. Het verschil tussen de twee onderzoeksgroepen lag daarin dat bij de deelnemers aan het maatwerkprogramma expliciet verband werd gelegd tussen de invloed van de variabelen uit het TPB-model (attitude, ervaren controle en sociale norm) op het te leren gedrag en het effect daarvan op lange termijn. Met behulp van een schriftelijke vragenlijst is het gedrag van alle participanten gemeten en zijn de effecten van de training in kaart gebracht, zowel direct na afsluiting van de training als drie maanden daarna. Afhankelijk van de behoeften van de deelnemers is in het maatwerkprogramma met behulp van de uitkomsten van de vragenlijst specifiek aandacht geschonken aan de barrières die effectief gedrag belemmeren. Bij de deelnemers aan het standaardprogramma is daarentegen geen verband gelegd tussen de uitkomsten van de vragenlijst en hun persoonlijke leerdoelen.

\section{Theoretische achtergrond}

Gedragsverandering is een complex en moeilijk te voorspellen proces. Diverse variabelen zoals de sociale omgeving, emotionele en cognitieve factoren, de ervaren noodzaak voor bepaald gedrag, de ondersteuning vanuit de omgeving en dergelijke zijn daarbij bepalend voor het daadwerkelijke resultaat (Thierry, I992). Vanuit de sociale leerpsychologie wordt gedragsverandering gedefinieerd als een relatief blijvende verandering van potentieel gedrag als gevolg van oefening en ervaring (Cherrington, 1994; eigen vertaling). De diverse aan gedragsverandering gerelateerde mechanismen of processen vertonen onderling grote verschillen. Deze verschillen zijn niet alleen van wetenschappelijk belang; zij hebben ook invloed op de wijze waarop een organisatie denkt het gedrag van medewerkers te kunnen meten en beïnvloeden (Goldstein \& Ford, 2002). Aanhangers van primair op beloning gerichte benaderingen baseren hun kennis onder andere op straf- en beloningsmechanismen en de sociale leertheorie (Bandura, I977; I986). Het succes van specifiek gedrag wordt verondersteld afhankelijk te zijn van de aan dit succes gekoppelde beloning, waarbij de omgeving een bevorderende invloed op het uiteindelijke resultaat heeft. Trainingen die hierop gebaseerd zijn richten zich met name op het aanleren van voorbeeldgedrag. Deze benadering was met name in de jaren vijftig van de vorige eeuw erg populair, waarbij de persoon wel werd vergeleken met een machine die geoptimaliseerd diende te worden. Later wordt in dit verband ook verwezen naar het begrip self-efficacy, dat refereert aan de mate waarin een persoon verwacht in staat te zijn bepaald gedrag te vertonen. Anderen spreken liever van een cognitief verwerkingsproces waarbij het doel en de evaluatie van gewenst gedrag vooropstaan (Deci, I975; Locke \& Latham, 1990). Met name in de jaren zeventig 
hebben trainingen zich steeds meer gericht op het bieden van inzicht in de eigen vermogens. Recent onderzoek naar de effectiviteit en de transfer van opleidingen richt zich vooral op de leercondities, waarbij een veel voorkomende veronderstelling is dat duurzame gedragsverandering pas mogelijk is als mensen het tijdens een training aangeleerde gewenste gedrag daadwerkelijk kunnen toepassen in de praktijk en daarvoor ook nog eens zelf verantwoordelijk zijn (Dewulf, 2003). Met name in het onderwijs heeft deze veronderstelling veel aandacht gekregen. Onder andere vindt De Vries (2003) een verband tussen leerresultaten, motivatie en eigen verantwoordelijkheid van de leerling binnen het biologieonderwijs op vwo-niveau. Hierbij heeft De Vries (2003) laten zien dat een procesgerichte leeraanpak waarin de individuele leerbehoeften van de leerling centraal staan en 'de verantwoordelijkheden voor het eigen leerproces worden overgenomen van de docent' meer diepgang opbouwt van betekenisvolle biologische kennis. Hij pleit er dan ook voor dat leerlingen vaker wordt gevraagd te reflecteren over dat wat zij hebben geleerd en daarbij op hun eigen bijdrage (verantwoordelijkheid) worden gewezen.

Salas en Cannon-Bowers (200I) geven een goed overzicht van de ontwikkelingen binnen het onderzoek naar trainingen in de afgelopen tien jaar. Zij merken op dat onderzoek zich steeds meer richt op deelaspecten binnen de trainingsomgeving en onderscheiden daarin vijf stromingen:

1 Theoretische ontwikkelingen, gericht op concepten en de verklaring voor gedragsverandering ('hoe werkt een bepaalde training/interventie?').

2 Organisatieanalyse, waarbij de werk- en taakgerelateerde condities waaronder bepaalde resultaten worden behaald, onderzocht en bijgestuurd worden ('onder welke organisatiegebonden condities werkt de training/interventie het best?').

3 Trainingscondities, hierbij staan cognitieve verwerkingsprocessen, self-efficacy, doelgerichtheid en motivatietheorieën centraal ('wat heeft de meeste invloed op de participanten?').

4 Trainingsmethoden en -instructies, die zich met name richten op leeraanpak, leertechnieken, technologische ondersteuning en simulaties ('op welke manier kan het trainingsproces worden gefaciliteerd?').

5 Posttrainingcondities, waarbij de evaluatie van het effect of design, en de transfer van de training centraal staan ('wat zijn de effecten van de training/interventie op langere termijn?').

Salas en Cannon-Bowers concluderen dat er op dit moment meer theorieën, modellen en empirische resultaten beschikbaar zijn dan ooit tevoren. Zij betwijfelen echter sterk of de aanwezige kennis wel invloed heeft op de aanpak van trainingen in organisaties. In de praktijk veranderen deze nauwelijks, wat Salas en CannonBowers doet concluderen dat de praktijk onvoldoende gebruikmakt van de inmiddels aanwezige kennis en ervaring. Zij benadrukken dat toekomstig onderzoek zich meer zou moeten richten op de praktische toepassing van deze kennis (Salas \& Cannon-Bowers, 200I).

Theory of Planned Behavior. In dit onderzoek staat de vraag centraal of een maatwerkprogramma van een communicatietraining een betere en meer langdurige verandering van gedrag tot gevolg heeft dan een standaardprogramma. In de geest van Salas en Cannon-Bowers (200I) ligt de nadruk bij deze training op de integratie van 
reeds bestaande kennis van organisatieanalyse, trainingscondities, trainingsmethoden en transfer, en niet op de ontwikkeling van een nieuw onderzoeksmodel. Een theoretisch kader dat goed aansluit bij het doel van de onderzochte training (gedragsverandering) en een verklaring geeft voor specifiek gedrag is de Theory of Planned Behavior van Ajzen (TPB, Ajzen, 1985, 1987, I99I). Hierbij wordt aangenomen dat gedragsvoornemens een goede voorspeller zijn voor het uiteindelijke gedrag in de praktijk (Fishbein \& Ajzen, 1975; Ajzen \& Fishbein, 1980). De fundamentele veronderstelling is dat naarmate het gedragsvoornemen sterker is, de kans dat een persoon ook daadwerkelijk in actie komt groter wordt (Schifter \& Ajzen, I985; Ajzen \& Madden, 1986). De mate van het gedragsvoornemen is daarbij afhankelijk van drie onderling samenhangende variabelen (zie figuur I): attitude, subjectieve norm en ervaren controle op gedrag.

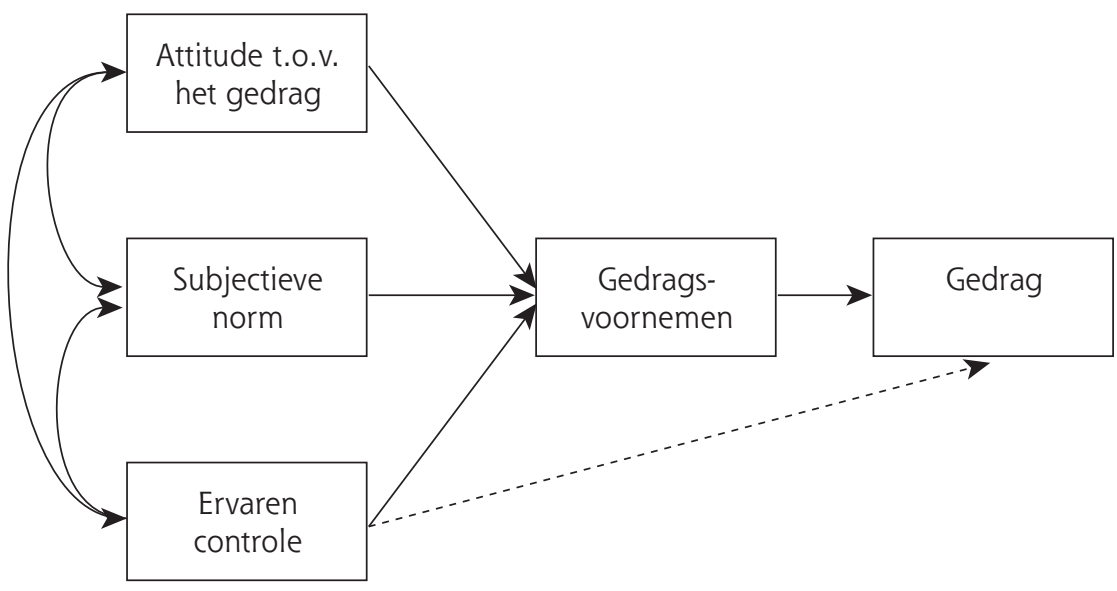

Figuur 1 De Theory of Planned Behavior (naar Ajzen, 1991)

Attitude wordt opgevat als een positief of negatief oordeel ten opzichte van het gewenste gedrag. Deze omvat ook de persoonlijke voor- en nadelen van het uiteindelijke gedrag en het daaraan gekoppelde urgentiebesef. Subjectieve norm verwijst naar de verwachtingen vanuit de sociale omgeving die een persoon ervaart ten opzichte van bepaald gedrag. De ervaren controle betreft de verwachting van een persoon dat hij of zij bepaald gewenst gedrag daadwerkelijk kan uitvoeren. Het weerspiegelt het vertrouwen dat iemand heeft in de eigen vaardigheden en welke barrières deze persoon verwacht. Tevens geeft Ajzen (I99I) aan dat ervaren controle ook direct invloed kan hebben op het gedrag, los van de gedragsvoornemens.

In de praktijk blijkt de TPB zeer bruikbaar voor de verklaring van gedrag (onder anderen Ajzen, I99I; Armitage \& Conner, 200r; Fishbein, Hennessy \& Douglas, 2003). Zo stellen Godin en Kok (1996) dat het TPB-model een goede basis is om het aan de gezondheid gerelateerde gedrag duidelijk te maken. Fishbein et al. (2003) vinden onder andere aanwijzingen dat deze drie variabelen een groot deel van de variatie in gedragsvoornemens verklaren. Een goede voorspellende waarde voor gedragsvoornemen vinden Kaiser en Gutscher (2003) bij het bepalen van milieu- 
bewust gedrag; de drie variabelen verklaarden samen maar liefst 8I\% van de variatie in het voornemen om milieubewust te handelen. Recent onderzoek van Ajzen, Brown en Carvajal (2004) laat zien dat gedragsintenties een goede voorspeller zijn voor daadwerkelijk gedrag, mits de variabelen van het TPB-model in een realistische context worden geplaatst. Voor gedragstraining is hiermee de mogelijkheid geboden om het effect op het beoogde gedrag door middel van de waargenomen gedragsintentie te bepalen, zonder dat (soms complexe en uit meerdere deelgedragingen bestaande) gedrag daadwerkelijk in te praktijk te hoeven meten. Abraham, Sheeran en Johnston (I988) benadrukken dan ook dat de voorspelling voor het gewenste gedrag beter wordt naarmate de omschrijving van het gedrag beter overeenkomt met de omschrijving van de gedragsvariabelen. Ajzen (I99I) ziet een grondige inventarisatie van de gevolgen die iemand in belangrijke mate verbonden ziet aan een bepaald gedrag als voorwaarde voor goed onderzoek. Verder neemt de voorspellende waarde van de gedragsintentie toe naarmate het gewenste gedrag specifieker omschreven is in termen van het doel van het gedrag, de situatie of context waarin het gedrag plaatsvindt, het tijdstip waarop het gedrag zou moeten plaatsvinden en de plaats waar het gedrag zou moeten plaatsvinden.

Intervention Mapping. Voor de praktische toepassing en de transfer van voorbeeldgedrag naar de praktijk (bijvoorbeeld in de gezondheidsvoorlichting en de gezondheidspsychologie) wordt veelvuldig gebruikgemaakt van Intervention Mapping (IM, Bartholomew, Parcel, Kok \& Gottlieb, 200r; Schaalma et al., 200r) als methode om gewenst gedrag op een systematische manier te verankeren. Daarbij wordt met behulp van een gestructureerde planmatige aanpak een maatwerkprogramma ontwikkeld, waarbij een duidelijke definitie en afbakening van het beoogde gedrag vooropstaat. Eén randvoorwaarde is dat het beoogde gedrag, de doelgroep en de daaraan verbonden belemmerende en bevorderende factoren voldoende duidelijk zijn. Na een dergelijk vooronderzoek behelst IM vijf opeenvolgende stappen die aan de daadwerkelijke interventie voorafgaan. Stap I is het meetbaar maken van het gewenste gedrag. Hiervoor moet specifiek worden vastgelegd wie, wat, wanneer, welk gedrag zal moeten vertonen. In stap 2 worden aan de hand van theoretische modellen en voorbeelden uit de praktijk interventiestrategieën ontwikkeld. In stap 3 worden deze strategieën omgezet in een interventieprogramma dat vervolgens in een pilot op toepassing en bruikbaarheid wordt getoetst. Vervolgens wordt in stap 4 nader onderzocht wie het programma uit moet voeren en welke randvoorwaarden noodzakelijk zijn voor succes. Uiteindelijk worden in stap 5 een evaluatieplan en methode ontwikkeld waarin het effect en de methode centraal staan. Het resultaat van deze stappen is een strategie om interventies te ontwerpen en het effect daarvan te meten. Tevens wordt optimaal gebruikgemaakt van bestaande expertise en kennis uit het verleden. Het ligt dus voor de hand om deze gestructureerde aanpak ook toe te passen op gedragstrainingen omdat deze zich niet zozeer richten op het verwerven van kennis, maar met name op het aanleren van gewenst of beter gedrag.

Op basis van het voorgaande verwachten we dat een volgens de principes van IM ontwikkeld maatwerkprogramma van een communicatietraining meer effect op het beoogde gedrag zal hebben dan een standaardprogramma; dat wil zeggen, de effecten van een maatwerkprogramma zullen tot betere en langdurigere effecten leiden dan een standaardprogramma. 


\section{Methode}

\subsection{Deelnemers}

Het onderzoek heeft plaatsgevonden binnen het reguliere opleidingsaanbod van een multinational met meer dan zesduizend medewerkers in Nederland. De organisatie is een productiebedrijf en bestaat uit meerdere zelfstandige businessunits. Iedere businessunit kan zelf trainingen en opleidingen organiseren en inkopen. Tevens worden de units ondersteund door een centrale afdeling Opleidingen die het gehele jaar vakspecifieke en meer op vaardigheden gerichte opleidingen aanbiedt. Deze opleidingen worden vaak door externe opleidingsinstituten verzorgd. De participanten hebben een brede achtergrond qua opleiding, functie en leeftijd en komen zowel uit de productie- als ondersteunende werkomgeving. Deelname geschiedt op volgorde van vrijwillige aanmelding, waardoor de trainingsgroepen heterogeen van samenstelling kunnen zijn. Het aantal aangeboden cursussen is afhankelijk van de hoeveelheid inschrijvingen en worden altijd aangeboden zodra de gewenste groepsgrootte van acht participanten is bereikt.

\subsection{Stimulusmateriaal}

Ontwerp van de training. De eerste auteur stelde samen met het hoofd van de centrale opleidingsafdeling en de personeelsfunctionarissen van de businessunits het onderzoeksdesign op. Daarbij zijn de onderzoeksmethode zoals omschreven door Schaalma et al. (200I) en de door Godin en Kok (1996) aanbevolen stappen in een gestructureerde aanpak uitgewerkt. Eerst zijn de belangrijkste gedragsdeterminanten geïnventariseerd, op basis waarvan een semi-gestructureerd interview werd samengesteld. Onder participanten uit eerdere trainingsgroepen is met behulp van dit interview onderzocht wat hun ervaringen voor, tijdens en na de cursus 'effectieve communicatie' waren, en hoe de in het TPB-model omschreven variabelen in de praktijk tot uiting kwamen. De uitkomsten van deze interviews werden door de eerste onderzoeker vertaald naar een vragenlijst die aansloot bij het TPB-model van Ajzen. Deze vragenlijst werd samen met de uitnodiging om aan de training deel te nemen, een vooropdracht en uitleg over het onderzoek naar alle toekomstige participanten gestuurd. De cursus bestond uit drie blokken van twee dagen (met steeds een tussenliggende periode van minimaal drie en maximaal vijf weken). Aan het begin van iedere bijeenkomst is steeds dezelfde vragenlijst onder alle participanten afgenomen. Voor de follow-upmeting is de vragenlijst per post verstuurd.

$\mathrm{Bij}$ de groep met een maatwerkprogramma kregen de trainer en de participanten informatie over de uitkomsten van iedere meting en oplossingsrichtingen aangeboden, die waren gebaseerd op het TPB-model. Tevens werden de leidinggevenden en de omgeving van de participanten waar nodig bij de leerdoelen betrokken. De inhoud van de training kon binnen de thema's worden aangepast aan de hand van de op basis van het TPB-model gevonden resultaten. De groep met een standaardprogramma kreeg geen oplossingsrichtingen aangeboden ten aanzien van de uitkomsten van de vragenlijst. Het essentiële verschil met de maatwerkgroep is dat bij de standaardgroep geen verband werd gelegd tussen (en ook geen discussie binnen de groep werd gevoerd over) de uitkomsten van het (voor)onderzoek en de leerdoelen van de participanten. Evenmin werd een op de TPB gebaseerd leerplan 
opgesteld. Wel moet nadrukkelijk worden opgemerkt dat ook de standaardgroep terugkoppeling kreeg over de hoogte van hun scores op de vragenlijst.

Het onderzoeksinstrument. In de beginfase van het onderzoek werd een onderzoeksinstrument ontwikkeld. Een groep bestaande uit twee personeelsfunctionarissen en twee trainers van het opleidingsinstituut stelde een lijst met de belangrijkste gedragsdeterminanten voor effectieve communicatie op, van waaruit een semigestructureerd interview werd samengesteld dat nauw aansloot bij het TPB-model. Van de in totaal Io8 aangeschreven participanten die reeds hadden deelgenomen aan de training reageerden 5 I personen $(47,2 \%)$ positief. In een periode van vier maanden is met al deze personen een semi-gestructureerd interview gehouden waarin werd onderzocht wat de belangrijke criteria zijn binnen het TPB-model. Hiervoor zijn vragen gesteld over het gedrag, de attitude, mogelijke drempels, randvoorwaarden, de ervaren controle en de subjectieve norm. Behalve een verduidelijking 10 van de te onderzoeken criteria gaven de interviews ook inzicht in randvoorwaardelijke factoren. Zo gaven de meeste participanten aan al in het begin van de cursus erg gemotiveerd geweest te zijn en dat het tijd nemen om met het nieuwe gedrag te kunnen oefenen in belangrijke mate bijdroeg tot het succes van de training. Desondanks bleek tijdens de interviews ook dat het voor complexere gedragingen moeilijk is om duidelijke gedragscriteria te formuleren zoals Fishbein en Ajzen (1975) die hanteren. De meest gebruikte omschrijvingen waren verzamelbegrippen voor een aantal gedragingen, zoals bijvoorbeeld 'ik heb een actieve luisterhouding' of 'ik geef feedback aan anderen'. Pas na doorvragen en het beschrijven van deelaspecten konden bruikbare gedragsbeschrijvingen geformuleerd worden. De attitude en subjectieve norm konden daarentegen wel duidelijk worden benoemd.

De uitkomsten van de interviews zijn door de eerste auteur vertaald naar een vragenlijst die aansluit bij het TPB-model van Ajzen (I99I). Deze vragenlijst bestond uit 35 onderzoeksvragen, 6 algemene vragen (demografische gegevens) en I open vraag. De vragenlijst is vervolgens aan I8 experts (trainers van het betrokken opleidingsbureau en $\mathrm{P} \& \mathrm{O}$-medewerkers) voorgelegd. In drie bijeenkomsten zijn díe vragen geselecteerd die door tenminste $80 \%$ van de experts aan de beoogde schaal toegewezen werden. Twee van de 35 onderzoeksvragen voldeden niet aan dit criterium, maar deze werden, gezien het beperkte aantal vragen, bij het verdere onderzoek wel meegenomen. De vragenlijst is vervolgens bij I4 personen uit de doelgroep getoetst op betrouwbaarheid door de test-hertestbetrouwbaarheid te berekenen (gepaarde t-test) met een interval van vier weken tussen de eerste en tweede afname. De uitkomsten daarvan geven voor de meeste vragen een hoge stabiliteit weer (zie de bijlage). $\mathrm{Bij} 30$ onderzoeksvragen werd geen significant verschil aangetroffen tussen de eerste en de tweede meting. Bij 5 onderzoeksvragen werd wel een significant verschil aangetroffen $(\mathrm{p}<.05)$.

De vraag rijst of de in het onderzoeksmodel opgestelde schaalindeling ook in de praktijk kan worden aangetroffen. In het algemeen is het wenselijk om variabelen of schalen met behulp van een factoranalyse te identificeren. Gezien de geringe steekproefomvang ( $\mathrm{N}=\mathrm{I} 4$ ) werd echter de voorkeur gegeven aan een analyse waarbij Cronbach's $\alpha$ berekend werd over de schalen zoals die a-priori ontwikkeld waren. Daarbij werd met name gekeken naar de interne consistentie van de schaal, alsmede naar de mate waarin de vragen onderling positief correleerden (binnen een bepaalde schaal onge- 
acht de hoogte). De uitkomsten laten voor de gekozen schaalindeling een hoge $\alpha$ zien voor zowel de eerste meting, de tweede meting en voor beide metingen gezamenlijk, alpha varieert van .66 tot .82 (mediaan .75 , zie de bijlage). Wel werden 3 vragen aangetroffen die de betrouwbaarheid binnen de betreffende schaal negatief beïnvloedden. Bij de vaststelling van de definitieve vragenlijst zijn de volgende criteria gehanteerd: (I) De vragen werden door tenminste $80 \%$ van de experts toegewezen aan de beoogde schaal, (2) de vragen zijn over langere tijd onder gelijke omstandigheden redelijk stabiel in de test-hertestbeoordeling ( $p$ > .05), (3) Cronbach's $\alpha$ bedroeg voor de uiteindelijke schaal tenminste .70, en (4) alle items binnen de schaal moesten positief met de andere items correleren. Uiteindelijk zijn van de oorspronkelijke 35 onderzoeksvragen in totaal 8 items uit de vragenlijst verwijderd.

Attitude. De attitude ten aanzien van effectieve communicatie werd gemeten met 3 items. De items werden door $83 \%$ tot 100\% van de 18 experts aan deze schaal toegewezen. De gemiddelde scores op deze items verschilden niet significant over de twee metingen (p's > .05, wat suggereert dat de test-hertestbetrouwbaarheid [stabiliteit] van deze items in orde was), en de betrouwbaarheid van de schaal (Cronbach's $\alpha)$ bedroeg 0.76 .

Ervaren controle. Ervaren controle over het gewenste gedrag werd gemeten met 4 items. De items werden door $83 \%$ tot $94 \%$ van de beoordelaars aan deze schaal toegewezen, de scores op de items was stabiel over de tijd (test-hertestbetrouwbaarheid van $\mathrm{p}>$.05), en Cronbach's $\alpha$ was 0.77 .

Sociale norm. Dit begrip werd gemeten met 8 items. Deze items werden door $83 \%$ tot $94 \%$ van de beoordelaars aan deze schaal toegewezen, met een test-hertestbetrouwbaarheid van $p>.05$ en een Cronbach's $\alpha$ van 0.73 .

Gedragsintentie. De intentie om het in de training geleerde gedrag toe te passen werd gemeten met I2 items. Deze items werden door $83 \%$ tot 100\% van de beoordelaars aan deze schaal toegewezen, met een test-hertestbetrouwbaarheid van $\mathrm{p}>$ .05 en een Cronbach's $\alpha$ van 0.75 .

Verder zijn 7 algemene vragen opgenomen in de vragenlijst (leeftijd, opleiding en dergelijke). De onderzoeksvragen zijn terug te vinden in de bijlage.

\subsection{Procedure}

Ten behoeve van het definitieve onderzoek werden zes trainingsgroepen a-select in volgorde van aanmelding geselecteerd. Vier daarvan (totale $\mathrm{N}=35$ ) ontvingen het 'maatwerkprogramma', de overige twee groepen ( $\mathrm{N}=$ I9) kregen een standaardprogramma aangeboden. In beide gevallen werden de deelnemers vier maal ondervraagd, respectievelijk aan het begin van iedere trainingsbijeenkomst (het interval tussen de trainingsbijeenkomsten was drie tot maximaal vijf weken) en drie maanden na de laatste bijeenkomst. Door ziekte, onvolledig ingevulde vragenlijsten en nonrespons op de follow-upmeting was bij 15 participanten niet alle data over de vier metingen aanwezig. In totaal zijn de gegevens van 39 participanten in dit onderzoek verwerkt: 25 deelnemers bevonden zich in de groep met een maatwerkprogramma, de overige I4 deelnemers ontvingen een standaardprogramma. Met variantieanalyse werd onderzocht of de onderzoeksgroepen van elkaar verschilden met betrekking tot leeftijd, geslacht, opleiding, functie en burgerlijke staat. Zulks bleek niet het geval te zijn, multivariate $\mathrm{F}(5,37)<$ I.oo, ns. De gemiddelde leeftijd was 36 jaar, $52 \%$ van de 
participanten was vrouwelijk en $75 \%$ was getrouwd of samenwonend. Van de participanten hadden er 4 lager onderwijs als hoogste opleiding, 2r lager beroepsonderwijs, I9 hoger beroepsonderwijs en 9 participanten hadden een universitaire achtergrond. Statistische analyse. Voor de statistische verwerking is het wenselijk dat de groepsomvang zo groot mogelijk is. Derhalve is onderzocht of voor de uiteindelijke berekeningen de separate trainingsgroepen als één onderzoeksgroep konden worden gezien binnen hun eigen trainingsprogramma. Daarbij was het uitgangspunt dat de trainingsgroepen binnen hun programma (standaard, maatwerk) over de vier meetmomenten niet significant van elkaar zouden mogen verschillen. Deze aanname is met behulp van een multivariate variantieanalyse (MANOVA) getoetst. Voor de twee trainingsgroepen met een standaardprogramma is voor alle variabelen en over de vier meetmomenten geen significant verschil aangetroffen, $\mathrm{F}(\mathrm{I}, \mathrm{I} 3)=3 . \mathrm{I} 8, \mathrm{p}>.05$. Ook voor de vier trainingsgroepen met een maatwerkprogramma is op de vier meetmomenten geen significant verschil aangetroffen, $\mathrm{F}(3,24)=\mathrm{I} .4, \mathrm{p}>$.05. Een groepseffect binnen de onderzoeksgroepen kan dus worden uitgesloten. Derhalve kan voor de verdere berekeningen van twee onderzoeksgroepen worden uitgegaan. De aanname dat een maatwerkprogramma een sterker en langduriger effect op het beoogde gedrag zal hebben dan een standaardprogramma werd in eerste instantie getoetst door middel van een 2 (Groep: maatwerk vs. standaardtraining) x 4 (Tijd: voor, tijdens, na en follow-up) variantieanalyse met herhaalde metingen op Tijd, voor elk van de vier criteriumvariabelen (attitude, controle, sociale norm en gedragsintentie) afzonderlijk. Wanneer deze analyse aangaf dat er een multivariaat hoofdof interactie-effect was, werd dit effect verder uitgewerkt door middel van univariate variantieanalyses. Ten slotte werd via lineaire regressieanalyse de verklarende waarde van de drie criteriumvariabelen op de gedragsintentie berekend (verklarende waarde van attitude, controle, sociale norm op de gedragsintentie).

\section{Resultaten}

\section{Vergelijking van gemiddelden}

Een eerste vergelijking van de somscores op de vier te onderzoeken variabelen tussen de groep met een maatwerkprogramma en de groep met een standaardprogramma laat een duidelijk verschil zien in de ontwikkeling van de onderzochte variabelen gedurende de vier metingen. Voor een goede weergave van het verloop binnen de onderzoeksgroepen zijn de gemiddelden omgezet in somscores en zijn deze in een grafiek weergegeven (figuur 2).

Bij de groep met een standaardprogramma is voor geen van de vier criteriumvariabelen een duidelijke ontwikkeling waar te nemen. Bij de groep met een maatwerkprogramma is echter een duidelijk verschil zichtbaar tussen de follow-upmeting en de voormeting. Voor alle vier variabelen is er sprake van een sterke stijging tussen meting I en meting 2. In de daaropvolgende metingen vlakt de stijging af. Op het eerste gezicht lijkt er dus een verband te zijn tussen type training en tijd. Deze indruk wordt bevestigd door vier Tijd x Groep-variantieanalyses (één per criterium- 
Uitkomsten attitude

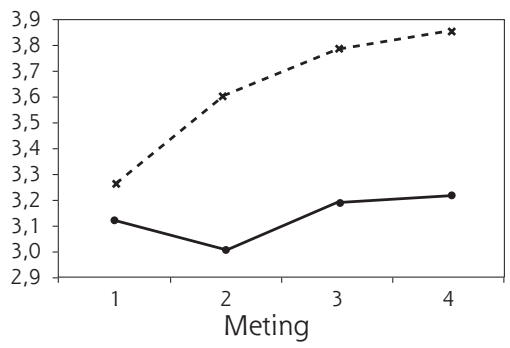

Uitkomsten controle

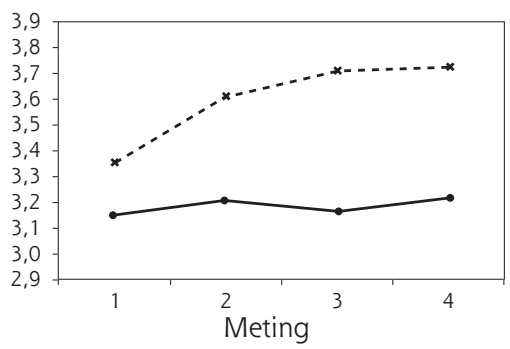

Uitkomsten sociale norm

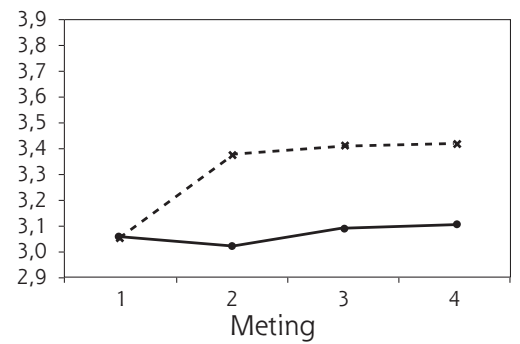

Uitkomsten voorgenomen gedrag

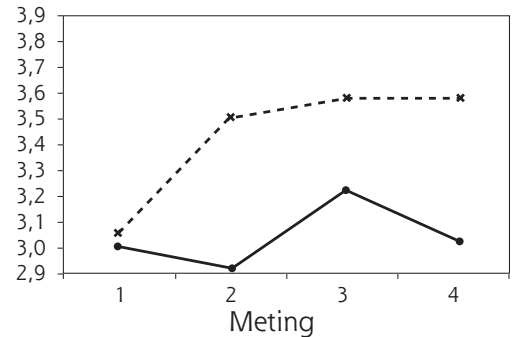

$\longrightarrow$ Standaard

-........ Maatwerk

Figuur 2 Relatieve scores over alle vier metingen

variabele), waarin steeds zowel de hoofdeffecten van Tijd en Groep als de Tijd x Groep-interactie statistisch significant zijn (tabel I).

Tabel 1 F-waarden voor de effecten van Tijd, Groep en Tijd x Groep ${ }^{a}$

\begin{tabular}{lrrrr}
\hline $\begin{array}{l}\text { Effect } \\
\text { Gedragsintentie }\end{array}$ & \multicolumn{2}{l}{ AttitudeSociale Norm } & Controle \\
\hline F(Tijd) & $8.05^{* *}$ & $4.84^{* *}$ & $3.02^{*}$ & $17.70^{* *}$ \\
\hline F(Groep) & $14.00^{* *}$ & $15.01^{* *}$ & $19.29^{* *}$ & $26.13^{* *}$ \\
\hline F(Tijd x Groep) & $4.49^{* *}$ & $4.81^{* *}$ & $1.56^{*}$ & $23.55^{* *}$ \\
\hline
\end{tabular}

aNB: Alle vergelijkingen hebben $(3,35)$ vrijheidsgraden.

${ }^{*} p<.05,{ }^{* *} p<.01$.

Univariate follow-upanalyses laten zien dat er op tijdstip I (vóór aanvang van de training) geen significant verschil is tussen de onderzoeksgroepen op alle variabelen uit het TPB-model, alle $\mathrm{F}(\mathrm{I}, 38)<2 . \mathrm{I} 2$, alle p's > .05. Daarentegen worden voor alle latere metingen voor alle vier variabelen significante verschillen tussen de maatwerk- en de standaardgroep aangetroffen, alle F(I,38) > II.I5, alle p's < .or. In de standaardgroep worden geen significante hoofdeffecten van Tijd aangetroffen, alle $\mathrm{F}(3, \mathrm{II})<4.96$, alle p's > .05. Bij de maatwerkgroep wordt echter voor alle variabelen 
een significant hoofdeffect van Tijd aangetroffen, alle $\mathrm{F}(3,22)>3.6 \mathrm{I}$, alle p's < .05. Op basis van deze gegevens kan worden aangenomen dat de uitgangspositie voor alle participanten dezelfde was en dat verschillen tussen de groep met een maatwerkprogramma en de groep met een standaardprogramma aan de interventies moeten worden toegeschreven. Tabel I laat verder zien dat de verschillen tussen de twee groepen bij de laatste meting (drie maanden na afloop van de training) ongeveer even groot zijn als op Tijdstip 3, wat betekent dat het maatwerkprogramma ook na verloop van tijd nog duidelijk effectiever is dan het standaardprogramma. Onze aanname dat een volgens de principes van IM ontwikkelde maatwerk-communicatietraining meer effect op het beoogde gedrag zal hebben dan een standaardprogramma wordt door deze gegevens dus in sterke mate ondersteund.

Regressieanalyses. Als aanvulling op onze variantieanalyses is het interessant te onderzoeken in welke mate de drie variabelen in de TPB van invloed zijn op de intentie tot gedragsverandering. De uitkomst daarvan geeft een indicatie van de mate waarin de in dit onderzoek gebruikte vragenlijst verklarende waarde heeft voor de intentie van de deelnemers om het bedoelde gedrag te gaan vertonen, wat het gebruik van de TPB als theoretische achtergrond van onze training zou rechtvaardigen. Deze vraag is met behulp van een lineaire regressie getoetst. Hiervoor zijn de variabelen Attitude, Controle en Subjectieve Norm opgenomen als voorspellers van Intentie. Daarnaast werd onderzocht of deelname aan een specifiek trainingsprogramma invloed heeft op deze uitkomst.

Tabel 2 Regressieanalyse over de vier meetmomenten

\begin{tabular}{|c|c|c|c|c|c|c|c|c|}
\hline & & & & & ting 1 & Meting 2 & Meting 3 & Meting 4 \\
\hline Effect & Variabelen & Groep & Variabelen & Groep & Variabelen & in Groep & Variabelen & Groep \\
\hline R & .36 & .36 & .66 & .76 & .50 & .59 & .58 & .74 \\
\hline $\mathrm{F}$ & $1.72 * a$ & $1.29 * b$ & $8.85 * * a$ & $11.34 * * b$ & b $\quad 3.97 * a$ & $4.66 * * b$ & $6.03 * * a$ & $10.03 * * b$ \\
\hline
\end{tabular}

De uitkomsten van de regressieanalyse (tabel 2) laten een matige verklarende invloed op het gedragsvoornemen zien. Opvallend is dat sociale norm, attitude en controle ten tijde van de eerste meting relatief zwak samenhangen met de gedragsintentie $(\mathrm{R}=.36)$; groepslidmaatschap (i.c. het op de nominatie staan om de maatwerk- dan wel de standaardtraining te volgen) hangt op dat tijdstip niet samen met de gedragsintentie. Bij de tweede meting zien we daarentegen een sterke stijging (van $\mathrm{R}=.66$ naar .76 wanneer groepslidmaatschap wordt toegevoegd). Deze resultaten laten zien dat de groepen in het begin (eerste meting) niet van elkaar verschilden, terwijl de regressiecoëfficiënten voor zowel de variabelen uit het TPBmodel als voor de deelname aan een maatwerkprogramma pas na de interventie stijgen. De deelname aan het maatwerkprogramma verklaart hierbij een groot deel van het verschil tussen de groepen, waardoor kan worden aangenomen dat een maatwerkprogramma gebaseerd op het TPB-model en Intervention Mapping een beter resultaat voorspelt dan een standaardprogramma. Minder uitgesproken zijn de 
gevonden resultaten op de afzonderlijke onderzoeksvariabelen attitude, controle en sociale norm. Zo blijkt slechts de variabele 'attitude' in de tweede meting een significante invloed te hebben op het daadwerkelijke gedragsvoornemen ( $\beta=.40$; $\mathrm{t}=2.98$; $\mathrm{p}$. . II) en kan men aannemen dat, naast de deelname aan het maatwerkprogramma, de attitude na de eerste interventie de beste voorspelling geeft voor het gedragsvoornemen. Bij alle andere metingen bleken de variabelen geen significante verklaring te geven van het gedragsvoornemen $(ß<.40 ; t<2.0 ; p>.05)$.

\section{Conclusie}

In dit onderzoek stond de vraag centraal of een via Intervention Mapping ontwikkelde maatwerk-communicatietraining gebaseerd op het TPB-model een sterker en langduriger effect op het beoogde gedrag zou hebben dan een standaard-communicatietraining. Onze resultaten laten ten eerste zien dat het TPB-model een bruikbare theoretische invalshoek is bij het ontwerp van een op gedragsverandering gerichte training. Bovendien biedt de in het onderzoek gebruikte vragenlijst de mogelijkheid het effect van een training te evalueren en positief te beïnvloeden. Ten tweede bleek dat Intervention Mapping (IM) als praktische aanpak voor gedragsverandering de opbrengst van een op gedrag gerichte training duidelijk verbeterde. De door Schaalma et al. (200I) beschreven onderzoeksopzet en de door Godin en Kok (I996) aanbevolen stappen bieden een goede richtlijn om heldere doelen te stellen en het effect van gedragsverandering op langere termijn op niveau te houden. Daarbij is een significante verbetering op alle variabelen voor de experimentele groep aangetroffen, in tegenstelling tot de controlegroep waarbij geen significante veranderingen werden waargenomen. De follow-upmeting na circa drie maanden toont aan dat de experimentele groep ook na de training de gevonden verbeteringen blijft behouden.

\section{Beperkingen van de studie}

Dit onderzoek kent een aantal beperkingen. Ten eerste is er sprake van een kleine steekproefomvang $(\mathrm{N}=39)$, wat betekent dat allerlei statistische methoden niet of minder goed bruikbaar zijn en dat de statistische power van wél bruikbare toetsen vermindert. Zo was factoranalyse zeer bruikbaar geweest bij de constructie van de uiteindelijke schaal. Deels zijn deze belemmeringen opgelost door de validatie en betrouwbaarheidsanalyse van de vragenlijst. Tevens suggereerden de uitkomsten van de analyses dat we over voldoende statistische power beschikten: de significante verschillen tussen de onderzoeksgroepen en de ontwikkelingen in de tijd maken het onaannemelijk dat gebrek aan statistische power de resultaten sterk vertekend heeft. Een tweede beperking van dit onderzoek is dat we gebruikmaakten van een zelfbeoordeling voor de beoordeling van gedrag als uitkomstmaat. Dit zou tot een geflatteerde samenhang tussen de onderzochte variabelen kunnen leiden. Hier staat tegenover dat een dergelijke samenhang dan naar verwachting ook in de regressieanalyses naar voren had moeten komen, wat niet het geval was.

Een derde probleem betreft de lage verklaarde varianties in onze studie. Eén reden daarvoor is dat het te veranderen gedrag (communicatiegedrag) een complex gegeven is en diverse deelgedragingen het gericht beïnvloeden van één enkel gedrags- 
aspect belemmeren. Daardoor is het moeilijk om te voldoen aan Fishbein en Ajzen's criteria dat 'het doel, de situatie of context, het tijdstip en de plaats' bij de meting van het te vertonen gedrag eenduidig omschreven moeten worden. In de praktijk blijkt communicatiegedrag uit diverse deelgedragingen te bestaan. Zo bestaat de vaardigheid 'actief luisteren' uit zowel oogcontact, knikken, samenvatten en dergelijke. Fishbein en Ajzen (1975) benadrukken dat naarmate de omschrijving van het te onderzoeken gedrag beter overeenkomt met bovengenoemde voorwaarden ten opzichte van de gedragsdeterminanten, de voorspellende waarde van dit model toeneemt (Abraham, Sheeran \& Johnston, I988). In eerdere studies naar bijvoorbeeld het gebruik van handschoenen onder verpleegkundigen (Levin, I999) en het inleveren van oud papier (Boldero, 1995) zijn beduidend hogere verklaarde varianties gevonden dan in onze studie. Kennelijk heeft de specificiteit van het te onderzoeken gedrag invloed op de onderzoeksuitkomsten en is het relatief moeilijk om complex gedrag te verklaren vanuit de TPB.

Ten vierde zou men kunnen veronderstellen dat de deelnemers aan het maatwerkprogramma meer aandacht of feedback hebben ontvangen dan de deelnemers in de standaardgroep en daardoor het effect in grote mate zou kunnen zijn beïnvloed. In de praktijk kregen alle deelnemers feedback op hun gedrag. In de standaardaanpak was dat voorzien tijdens oefeningen en in gesprekken met mededeelnemers. Het verschil met het maatwerkprogramma lag met name in het expliciet koppelen van het TPB-model aan de leerdoelen van de deelnemers en de uitkomsten van de vragenlijst (i.e. het type feedback verschilde, maar de hoeveelheid niet). Door de eerste onderzoeker is aan de deelnemers van beide programma's gemiddeld I uur extra uitleg en toelichting per deelnemer gegeven. Tijdens de training is bij het maatwerkprogramma expliciet aandacht geschonken aan het TPB-model. Het is dus niet aannemelijk dat de verschillen tussen beide groepen deelnemers veroorzaakt zijn door grote verschillen in de mate van aandacht die zij ontvingen.

Implicaties. In dit onderzoek hebben wij laten zien dat succesvolle modellen binnen diverse disciplines ook binnen andere toepassingsdomeinen hun toegevoegde waarde hebben. Daar waar het om gedragsverandering gaat zijn het TPB-model (Ajzen, I99I) en een aanpak gebaseerd op Intervention Mapping (Bartholomew et al., 200I; Schaalma et al., 200I) een zinvolle basis om gedrag effectief en op langere termijn te beïnvloeden. Met name bij de tweede bijeenkomst van onze training (waarin nadrukkelijk het TPB-model aan bod kwam) bleek onze interventie een duidelijk positief effect te hebben. Hoewel de doelstelling en het programma van beide trainingsgroepen gelijk waren, is in het maatwerkprogramma meer de nadruk gelegd op de behoeftes van de deelnemers. Afhankelijk van de uitkomsten uit de vragenlijst is aan de te behandelen onderwerpen meer of minder aandacht besteed. Tevens benadrukt het TPB-model de transfer naar de dagelijkse praktijk door barrières op te sporen en te benoemen. In de groep met het standaardprogramma zijn dezelfde onderwerpen als in de maatwerkgroep behandeld, waarbij het design en de transfer naar het werk echter niet nadrukkelijk aan bod kwamen. Deze groep laat een meer grillig verloop in hun antwoorden op de vragenlijst zien. Op zich is dat geen verwonderlijke uitkomst: de in deze groep aanwezige 'sinuscurve' wordt bijvoorbeeld ook door De Caluwé (1997) beschreven. Hij benadrukt dat het leerproces gewoonlijk onregelmatig verloopt: participanten leren nieuwe dingen, merken dat 
het tegenvalt en leren opnieuw. In deze zin is bij de controlegroep een 'klassiek' leerpatroon aanwezig. De interventies in het maatwerkprogramma zijn veel meer gericht op de in het TPB-model omschreven variabelen en verschaffen de participant inzicht in diens functioneren en hoe deze in het proces de uitkomst (gedrag) zelf kunnen beïnvloeden. Op deze manier lijkt het leerproces efficiënter te kunnen verlopen, zonder de ups en downs die het leerproces vaak kenmerken. In deze zin biedt het TPB-model een toegevoegde waarde bij leer- en veranderprocessen. IM kan daarbij als een mogelijke katalysator gezien worden omdat de voorgeschreven stappen een strategie vormen voor het ontwerp van een interventieprogramma zonder uitspraken te doen over de interventies zelf. Hierdoor wordt optimaal gebruikgemaakt van aanwezige kennis die ook specifieker aansluit bij de doelgroep.

Hoewel deze studie de nodige beperkingen kent, kunnen we toch op basis van de aangetroffen resultaten een aantal aanbevelingen formuleren. Ten eerste, onze studie laat zien dat een maatwerkprogramma duidelijk betere resultaten oplevert dan een standaardprogramma. Dit geldt in het bijzonder voor een trainingssituatie waarin naast kennisoverdracht en het aanleren van deelvaardigheden, het programma er ook op gericht is om de deelnemer inzicht te verschaffen in diens invloed op de transfer naar de praktijk.

Deze bevindingen zijn in overeenstemming met de aanbevelingen van Schaalma (1993) en Schaalma et al. (200I). Zowel TPB als IM bleek een zeer bruikbaar middel te zijn om maatwerktrainingen te ontwikkelen. Bij het ontwerp en de toepassing van (gedrags)trainingen dient men het gewenste gedrag dus zoveel mogelijk 'meetbaar' te maken. Vervolgens zou veel meer naar 'best practices' gezocht moeten worden om een doeltreffend trainingsprogramma te ontwikkelen. Voorts zou bij het ontwerpen van trainingen ook actief naar randvoorwaarden voor de toepassing van de aangeleerde kennis en vaardigheden moeten worden gezocht. Ten slotte dient de gewenste verandering behalve te worden gemeten ook op termijn te worden geëralueerd. In dat verband is IM het middel bij uitstek om een bij de situatie en de doelgroep passende leerstrategie te ontwerpen en het effect daarvan te meten. Organisaties, deelnemers en aanbieders van trainingen zouden er baat bij hebben voor iedere interventie en/of training een antwoord te formuleren op de uit IM voortvloeiende vragen:

1 Wat is het probleem en daardoor het doel van de training?

2 Hoe kunnen de effecten gemeten worden?

3 Welke interventiestrategieën/oplossingen zijn al bekend?

4 Welke barrières kunnen deelnemers tegenkomen?

5 Hoe moet de transfer naar de praktijk gerealiseerd worden?

6 Wat kan iedereen van het gehele proces leren?

Hierdoor is tevens de kans groter dat de binnen verschillende onderzoeksterreinen aanwezige kennis en informatie benut en in een bredere context toegepast wordt. Toekomstig onderzoek zou zich dan ook veel meer moeten richten op de integratie van de diverse methoden dan op diversificatie daarvan. 


\section{Dankwoord}

Dit onderzoek heeft kunnen plaatsvinden dankzij de medewerking van en ondersteuning door Schouten \& Nelissen te Zaltbommel.

\section{Literatuur}

Abraham, C., Sheeran, P. \& Johnston, M. (1988). From health beliefs to self regulation: Theoretical advances in the psychology of action control. Psychology and Health, I3, 569-591.

Ajzen, I. \& Fishbein, M. (1980). Understanding attitudes and predicting social behavior. Englewood Cliffs (NJ): Prentice Hall.

Ajzen, I. (1985). From intentions to actions: a theory of planned behavior. In J. Kuhl en J. Beckmann (red.), Action-control: from cognition to behavior (pp. II-39). Berlin: Springer.

Ajzen, I. (1987). Attitudes, traits, and actions: dispositional prediction of behavior in personality and social psychology. Advances in Experimental Social Psychology, 20, I-63.

Ajzen, I. (I99I). The theory of planned behavior. Organizational Behavior and Human Decision Processes, 50, I79-2II.

Ajzen, I., Brown, T.C. \& Carvajal, F. (2004). Explaining the discrepancy between intentions and actions: The case of hypothetical bias in contingent validation. Personality and Social Psychology Bulletin, vol. 30, 9, IIO8-II2I.

Ajzen, I. \& Madden, T.J. (I986). Prediction of goal-directed behavior: attitudes, intentions and perceived behavioral control. Journal of Experimental Social Psychology, 22, 453-474.

Armitage, C.J. \& Conner, M. (200I). Efficacy of the theory of planned behavior: a metaanalytic review. British Journal of Social Psychology, 40, 471-500.

Bandura, A. (1977). Social learning theory. Engelwood-Cliffs: Prentice Hall.

Bandura, A. (I986). Social foundations of thought and action: a social cognitive theory. New York: Prentice Hall.

Bartholomew, K., Parcel, G., Kok, G. \& Gottlieb, N. (200I). Intervention Mapping: developing theory and evidence-based health education programs. Mountain View, CA: Mayfield.

Bender, R., Timmermans, N. \& Wesseling, A. (200I). Je kunt me nog meer vertellen. Zaltbommel: Thema.

Boldero, J. (1995). The prediction of household recycling of newspapers: The role of attitudes, intentions, and situational factors. Journal of Applied Social Psychology, 25, 440462.

Caluwé, L. de (1997). Veranderen moet je leren: over de opzet en effecten van een grootschalige cultuurinterventie met behulp van een spelsimulatie. Den Haag: Elsevier.

CBS (2002). Index, No.2; februari 2002. http://www.statline.cbs.nl.

Cherrington, D.J. (1994). Organizational behavior. Nedham Heights, MA: Allyn and Bacon.

Deci, E.L. (1975). Intrinsic motivation. New York: Plenum Press.

Dewulf, L (2003). Gras groeit niet door er aan te trekken. Opleiding en Ontwikkeling, I6, 38.

Dijk, C. van (1998). Assertief op het werk. Zaltbommel: Thema.

Fishbein, M. \& Ajzen, I. (I975). Belief, attitude, intention and behavior: an introduction to theory and research. Reading, MA: Addison-Wesley.

Fishbein, M., Hennessy, M. \& Douglas, J. (2003). Can we explain why some people do and some people do not act on their intentions? Psychology, Health and Medicine, 8, 3-18.

Godin, G. \& Kok, G. (1996). The theory of planned behavior: A review of its applications to health-related behaviors. American Journal of Health Promotion, II, 87-98.

Goldstein, I.L. \& Ford, J.K. (2002). Training in organizations. Belmont, CA: Wadsworth. 
Kaiser, F.G. \& Gutscher, H. (2003). The proposition of a general version of the theory of planned behavior: Predicting ecological behavior. Journal of Applied Social Psychology, 33, 586-6o3.

Lakerveld, J. van, Oudendammer, F. den \& Stam, D. (2003). Als het tij verloopt, moet men de bakens verzetten: inventarisatie van trends in de branche van bedrijfsopleiders. Leiden: Plato Kennisbalans.

Levin, P.F. (1999). Test of the Fishbein and Ajzen models as predictor of health care worker's glove use. Research in Nursing and Health, 22, 295-307.

Locke, E.A. \& Latham, G.P. (I990). A theory of goal setting and task performance. New Jersey: Englewood Cliffs.

Ouden, M. den (1992). Transfer na bedrijfsopleidingen. Amsterdam: Thesis Publishers.

Salas, E. \& Cannon-Bowers, A. (200I). The science of training: a decade of progress. Annual Review of Psychology, 52, 471-499.

Schaalma, H. (1993). De analyse van gedragsdeterminanten. In V. Damoiseaux, H. van der Molen en G. Kok (red.), Gezondheidsvoorlichting en gedragsverandering (pp. 133-167). Assen: Van Gorcum.

Schaalma, H., Kok, G. \& Meertens, R.M. (20or). Intervention mapping. In J. Brug, H. Schaalma, G. Kok, R.M. Meertens en H.T. van der Molen (red.), Gezondheidsvoorlichting en gedragsverandering: een planmatige aanpak (pp. 73-88). Assen: Van Gorcum.

Schifter, D.B. \& Aijzen, I. (1985). Intention, perceived control and weight loss: an application of the theory of planned behavior. Journal of Personality and Social Psychology, 49, 843-851.

Thierry, Hk. (1992). Motivatie en satisfactie. In P.J.D. Drenth, Hk. Thierry, en Ch.J. de Wolff (red.), Nieuw bandboek arbeids- en organisatiepsychologie (pp. 3-69). Houten: Bohn Stafleu van Loghum.

Vries, H. de, Weijts, W., Dijkstra, M. \& Kok, G. (1992). The utilization of qualitative and quantitative data for health education program planning, implementation, and evaluation: A spiral approach. Health Education Quarterly, I9, IOI-II5.

Vries, R.R.M. de (2003). Procesgericht biologieonderwijs. Eindhoven: TU.

\section{Summary}

\section{Effectiveness of a communication training: A comparison between a tailor-made and a standard approach}

Michael Rauner, Gerjo Kok \& Toon Taris, Gedrag \& Organisatie, Volume 19, Maart 2006, nr. 1, pp. 3-21

Long-term behavior change as a result of a training intervention is difficult to achieve. The present study assumes that a training will have a stronger impact when (1) a theory-based intervention program is used (in this case based on Ajzen's [1991] Theory of Planned Behaviour), and (2) if a structured approach is applied (Intervention Mapping, Bartholomew et al., 2001). Using a supervised control $(N=19)$ - experimental $(N=35)$ group design, the present study showed that the TPB-model can be used to frame desirable behaviour and to measure the outcome of the intervention. IM appeared an effective method to influence behaviour in the desired way. During the whole intervention the intervention group showed significantly more improvement on the TPB variables (attitude, subjective norm, perceived behavior and intention) than the control group.

Key words: training, planned behavior, Intervention Mapping, evaluation 


\section{Bijlage Resultaten van de vragenlijstontwikkeling}

\section{T-waarde}

\begin{tabular}{|c|c|c|c|}
\hline $\begin{array}{c}\text { Expert } \\
\text { validatie } \\
(\mathrm{N}=18)\end{array}$ & $\begin{array}{c}\text { Test- } \\
\text { Hertest } \\
\text { Betrouw- } \\
\text { baarheid } \\
(\mathrm{N}=14)\end{array}$ & $\begin{array}{c}\text { Cronbach's } \\
\alpha \text { meting } \\
1 \text { \&2 } \\
(\mathrm{N}=14)\end{array}$ & $\begin{array}{l}\text { Definitief } \\
\text { uit de } \\
\text { vragenlijst } \\
\text { verwijderd }\end{array}$ \\
\hline
\end{tabular}

Attitude

Met een effectieve communicatie kan ik $\quad 83.3 \% \quad 1.32$

mijn werkprestatie verbeteren

\begin{tabular}{lll}
\hline Effectieve communicatie heeft voordelen & $94.4 \%$ & 0.39
\end{tabular}

voor mijn werk

\begin{tabular}{|c|c|c|c|c|}
\hline $\begin{array}{l}\text { Het heeft voor mij voordelen om mijn eigen } \\
\text { gedrag met EC in de toekomst te veranderen }\end{array}$ & $100.0 \%$ & 0.15 & & \\
\hline $\begin{array}{l}\text { Het is goed om je eigen communicatie te } \\
\text { willen verbeteren }\end{array}$ & $55.6 \%$ & 0.71 & & $* * *$ \\
\hline Ervaren controle & & & $\alpha=0.77$ & \\
\hline $\begin{array}{l}\text { Ik kan zelf een actieve bijdrage leveren } \\
\text { aan effectieve communicatie }\end{array}$ & $94.4 \%$ & 0.00 & & \\
\hline $\begin{array}{l}\text { Ik heb voldoende kennis om aan de } \\
\text { training een bijdrage te kunnen leveren }\end{array}$ & $88.9 \%$ & -1.00 & & \\
\hline $\begin{array}{l}\text { Ik heb voldoende randvoorwaarden om } \\
\text { effectief te communiceren }\end{array}$ & $100.0 \%$ & 0.15 & ** & $* * *$ \\
\hline $\begin{array}{l}\text { Ik ben zelf verantwoordelijk voor een } \\
\text { goede communicatie }\end{array}$ & $88.9 \%$ & -0.69 & & \\
\hline $\begin{array}{l}\text { Ik kan in mijn werk met ander gedrag } \\
\text { experimenteren }\end{array}$ & $83.3 \%$ & -1.32 & & \\
\hline
\end{tabular}

\section{Sociale norm}

$\alpha=0.73$

Mijn leidinggevende stimuleert mij in het

$94.4 \% \quad-0.37$

kader van deze training.

\begin{tabular}{lll}
\hline$k$ ben tevreden over de aansturing door & $83.3 \%$ & 0.56
\end{tabular}

mijn direct leidinggevende

Ik word door anderen gewaardeerd als ik $\quad 83.3 \% \quad 1.17$

mij inzet voor een goede communicatie

\begin{tabular}{lll}
\hline Mijn direct leidinggevende staat positief & $88.9 \%$ & 0.00
\end{tabular}

tegenover deze training (EC)

Ik ontvang uit mijn directe omgeving $\quad 94.4 \% \quad-0.56$

waardering voor mijn werk

\begin{tabular}{lll}
\hline Mijn collega's voelen zich verantwoordelijk $\quad 88.9 \%$ & 0.81
\end{tabular}

voor een goede communicatie

Mijn directe collega staat positief tegenover $\quad 88.9 \% \quad-2.51$ *

effectieve communicatie

Mijn collega's hebben een positieve

$88.9 \% \quad-0.43$

bijdrage aan mijn communicatie 


\section{T-waarde}

\begin{tabular}{cccc} 
Expert & Test- & Cronbach's & Definitief \\
validatie & Hertest & $\alpha$ meting & uit de \\
$(\mathrm{N}=18)$ & Betrouw- & $1 \& 2$ & vragenlijst \\
baarheid & $(\mathrm{N}=14)$ & verwijderd \\
$(\mathrm{N}=14)$ & & \\
\hline
\end{tabular}

\begin{tabular}{lcl}
\hline $\begin{array}{l}\text { Mijn partner (thuis) staat positief t.o.v. } \\
\text { mogelijke veranderingen in het werk }\end{array}$ & $88.9 \%$ & -0.96 \\
\hline $\begin{array}{l}\text { Ik hoor anderen waardering voor hun } \\
\text { werk te geven }\end{array}$ & $83.3 \%$ & $-2.28 *$ \\
\hline $\begin{array}{l}\text { Ik maak met de organisatie afspraken over } \\
\text { mijn persoonlijke ontwikkeling }\end{array}$ & $88.9 \%$ & -1.47 \\
\hline
\end{tabular}

\begin{tabular}{|c|c|c|c|c|}
\hline Intentie (resultaat) & & & $\alpha=$ & \\
\hline $\begin{array}{l}\text { Ik word door mijn omgeving op mijn } \\
\text { communicatie aangesproken }\end{array}$ & $55.6 \%$ & $-2.88 *$ & ** & *** \\
\hline $\begin{array}{l}\text { Mijn verschillende werkzaamheden en } \\
\text { resultaten zijn duidelijk omschreven }\end{array}$ & $88.9 \%$ & -1.38 & & \\
\hline $\begin{array}{l}\text { Effectieve communicatie geeft mij } \\
\text { een positief gevoel }\end{array}$ & $94.4 \%$ & $-3.71 *$ & & *** \\
\hline $\begin{array}{l}\text { Ik heb een actieve (luister)houding in de } \\
\text { interactie met anderen }\end{array}$ & $94.4 \%$ & 0.48 & & \\
\hline Ik geef feedback aan anderen & $100.0 \%$ & 0.00 & & \\
\hline Ik ga met plezier naar mijn werk & $83.3 \%$ & -1.15 & & \\
\hline Ik heb een actieve luisterhouding & $100.0 \%$ & 0.00 & & \\
\hline Ik sta open voor de mening van anderen & $88.9 \%$ & 0.81 & & \\
\hline $\begin{array}{l}\text { Ik heb duidelijke ontwikkelafspraken } \\
\text { (leerdoelen) over EC gemaakt }\end{array}$ & $88.9 \%$ & -1.38 & & \\
\hline $\begin{array}{l}\text { Ik geef op een productieve manier kritiek } \\
\text { op anderen }\end{array}$ & $100.0 \%$ & 0.00 & & \\
\hline $\begin{array}{l}\text { Er worden goede afspraken over het werk } \\
\text { gemaakt }\end{array}$ & $100.0 \%$ & 0.00 & & \\
\hline $\begin{array}{l}\text { Ik neem eigen initiatief in het werk om de } \\
\text { nodige dingen op te pakken }\end{array}$ & $88.9 \%$ & 2.12 & & \\
\hline $\begin{array}{l}\text { Mijn collega's staan open voor de mening } \\
\text { van anderen }\end{array}$ & $88.9 \%$ & -0.56 & & \\
\hline Er wordt duidelijk gecommuniceerd & $88.9 \%$ & $5.63 *$ & & $* * *$ \\
\hline $\begin{array}{l}\text { Mijn collega's nemen initiatief in het werk } \\
\text { om de nodige dingen op te pakken }\end{array}$ & $88.9 \%$ & -1.47 & & \\
\hline
\end{tabular}

